Seminar Nasional Pendidikan Seni \#2 REORIENTASI PENDIDIKAN SENI DI INDONESIA Jurusan Pendidikan Seni Rupa FBS UNESA 2014 


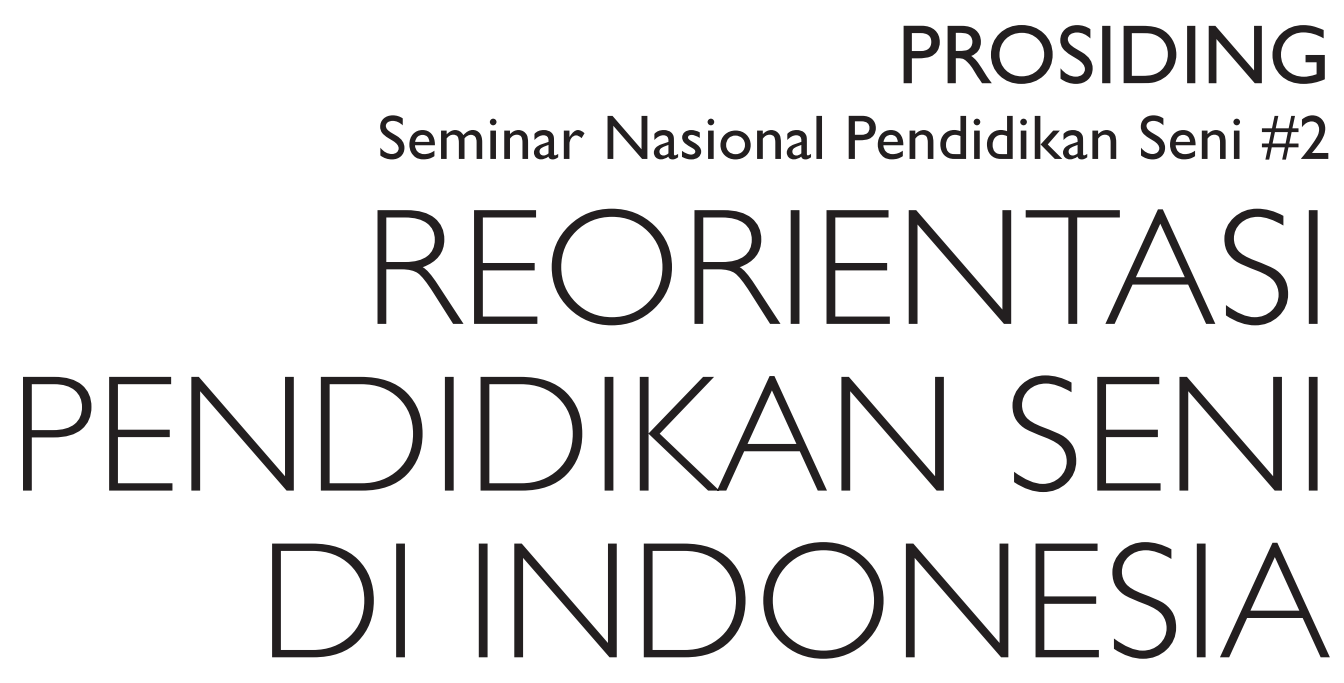


ISSN 2089-692 I

Prosiding Seminar Nasional Pendidikan Seni \#2 REORIENTASI PENDIDIKAN SENI DI INDONESIA

Surabaya, I5-16 Oktober 2014

Jurusan Pendidikan Seni Rupa, Fakultas Bahasa dan Seni

Universitas Negeri Surabaya

\section{Ketua Penyunting:}

Djuli Djatiprambudi

\section{Anggota Penyunting:}

Asidigisianti Surya Patria

Asy Syams Elya Ahmad

\section{Desain Sampul:}

Tri Cahyo Kusumandyoko

\section{Tata Letak:}

Asy Syams E. A. 
Daftar Isi

vii Reorientasi Pendidikan Seni di Indonesia

$\S \quad$ Makalah Pembicara Utama

1 Berpijak pada Kesekarangan untuk Mereorientasi Pendidikan Seni -M. Dwi Marianto

6 K U K I K O: Kursus Kilat Komposisi Diajarkan di Jakarta dan Surabaya Sejak 2012 —Slamet A. Sjukur

10 Pendidikan Seni di Era Multikultural - G. R. Lono Lastoro Simatupang

17 Reorientasi Pendidikan Seni Budaya di Zaman Global

—Djuli Djatiprambudi

$\S \quad$ Estetika dan Multikulturalitas dalam Pendidikan Seni

27 Pendidikan Estetis dalam Konteks Pendidikan Seni Budaya Rupa di Indonesia: Sebuah Kajian Teoritik —Mohammad Rondhi

40 Mengkaji Ulang Estetika Pada Pendidikan Seni: Estetika Nusantara Sebagai Haluan Pendidikan Seni Indonesia Masa Depan -Michael HB Raditya

48 Apropriasi Estetika dalam Seni Rupa Kontemporer:

Sebuah Pendekatan Paralogisme - Hajar Pamadhi

55 Pendekatan Feminis sebagai Pengembangan Pendidikan Seni Rupa di Perguruan Tinggi Seni Indonesia Berlandaskan Kesetaraan Jender -Ira Adriati

60 Reorientasi Wacana Ke-"Cina"-An Sebagai Pendidikan Multikultural Melalui Perfilman —Umilia Rokhani

Nilai Seni Budaya pada Kain Rangrang - Cut Kamaril Wardani

80 Nilai-nilai Pendidikan pada Tradisi Grebeg Suro di Ponorogo:

Relevansinya Terhadap Penciptaan Karakter Bangsa — Ratih Asmarani

85 Eksplorasi Nilai-nilai Budaya Jawa dalam Patung Loro Blonyo:Upaya Memperkaya Materi Pembelajaran Seni Budaya Berbasis Karakter -Slamet Subiyantoro

90 Menggugat Praktik "Kebutaan Bahasa Rupa" Relief Candi dalam Pembelajaran Seni Rupa Berbasis Local Genious —Dwi Budi Harto 


\section{Daftar Isi}

ISSN 2089-692I

98 Wayang Topeng Jati Duwur sebagai Modal Kreatif dalam Pendidikan Seni — Setyo Yanuartuti

105 Pertunjukan Wayang Kulit Bayangan 'Gara-gara’ Sebagai

Pembelajaran Karakter - Ika Ismurdyahwati

$\S \quad$ Eksplorasi Kreatif dalam Pembelajaran Seni

111 Proses Kreatif dalam Kegiatan Seni: Berfikir Integral yang Menstimuli Kreativitas Manusia - Nuning Y. Damayanti Adisasmito

119 Konstruktivisme Jean Pieget dalam Teori Bermain:

Suatu Pembelajaran Seni pada Anak —Daulat Saragi

124 Belajar dari Lukisan Anak — Muchammad Bayu Tejo Sampurno

132 Seni untuk Kehidupan: Upaya Masyarakat Urban Jakarta Berdamai dengan Gangguan Jiwa melalui Seni (Studi Kasus di Komunitas Peduli Skizofrenia Indonesia) — Caecilia Tridjata S.

139 Practice-led Research sebagai Alternatif Metodologi Riset Penciptaan Karya Seni Rupa di Indonesia; Sebuah Studi tentang Eksplorasi Kreatif Praktik Seni di Perguruan Tinggi — Aprina Murwanti

148 Revitalisasi Perguruan Tinggi Seni di Indonesia - Mira Sutrisna

154 Proses Kreasi Karya Seniman Kontemporer Indonesia Sebagai Bahan Materi Ajar Pada Mata Kuliah Metode Penciptaan Seni —Kiki Rizky Soetisna Putri

158 Penciptaan Ragam Hias Baru Berbasis Motif-motif Tradisional: Model Pendekatan Pembelajaran Seni Eksplorasi Kreatif

-Dwi Budiwiwaramulja

163 Eksplorasi Seni Tradisi dan Kerajinan sebagai Bahan Pendidikan Seni —Wahyu Tri Atomojo

167 Eksplorasi Motif Batik Jawa Timur dan Pewarnaan Alami untuk Pengembangan Perangkat Pembelajaran Kriya Tekstil

-Fera Ratyaningrum

174 Pengembangan Bahan Ajar Berbasis Keragaman Tanaman di Jawa pada Mata Kuliah Kerajinan Tekstil - Ismadi

179 Peningkatan Kualitas Tatap Muka Pembelajaran Seni Musik Pada Tingkat Sekolah Dasar Hingga Menengah Atas - A. Gathut Bintarto T. 
187 Pengembangan Materi Ajar Mata Kuliah Keahlian Program Studi Pendidikan Seni Musik dalam Konteks Pelaksanaan Pembelajaran Berbasis Action Learning di Sekolah -Udi Utomo

194 Musik Lesung Sebagai Sarana Ekspresi dan Kreasi Musik di SDN Ledok 1 Blora - Suharto

200 Buku Ajar Pendidikan Seni Terintegrasi dengan Pendidikan Kewirausahaan-Kreatif bagi Peningkatan Pola Pikir Entrepreneurial untuk Era Industri Kreatif - Moeljadi Pranata

207 Gambar Ilustrasi Buku Sekolah Dasar Ditinjau dari Teori Psikologi Persepsi — Asidigisianti Surya Patria

214 Eksplorasi Tanah Liat: Motivasi Peningkatan Kreativitas Guru TK Aba Kota Batu - Muchlis Arif

Aplikasi Teknik Kerok Pada Seni Lukis - Winarno

§ Implementasi Teknologi Media dalam Pembelajaran Seni

233 Revitalisasi Ragam Hias Adati Melalui Pengembangan Bahan Ajar Berbasis Blended Digital Media untuk Mahasiswa DKV UM -Pranti Sayekti

240 Proyek Film Indie sebagai Media Pembelajaran dalam Pendidikan Seni —Riksa Belasunda

245 Picture Exchange Communication System (PECS) Sebagai Media Pembelajaran dan Terapi Visual Bagi Siswa Berkebutuhan Khusus - Rudi Irawanto

250 Perancangan Multimedia Pembelajaran Apresiasi Seni Tradisi -Marsudi

256 Mengembangkan Teknologi dalam Media Pembelajaran Seni —Dody Doerjanto

262 Meningkatkan Kreativitas dalam Pembelajaran Animasi - Hendro Aryanto

266 Peranan Seni Rupa dalam Media Pembelajaran Inovatif -Rizki Taufik Rakhman 


\section{Daftar Isi}

ISSN 2089-692I

270 Pengaruh Penggunaan Media Pembelajaran yang Berbeda Terhadap Hasil Belajar Seni Rupa Siswa Kelas IX yang Memiliki Motivasi Belajar Berbeda - Yuni Egawati

$\S \quad$ Analisis Kritis Kurikulum 2013 Mata Pelajaran Seni Budaya

279 Perlunya Reorientasi Pendidikan Seni Budaya Problem Pendidikan Seni Budaya di Tingkat Pendidikan Dasar, Menengah, dan Tinggi -Agus Priyatno

286 Menyoal Paradigma Sains dalam Pendidikan Seni Kurikulum 2013 -Kasiyan

293 Guru Kreatif Kompetensi Kejuruan —Biwara Sakti Pracihara

297 Keunggulan dan Kelemahan Kurikulum 2013 Mata Pelajaran Pendidikan Seni Budaya Bidang Seni Rupa - Mudjiati

301 Peran Pendidikan Seni sebagai Subyek Berdiri Sendiri dalam Kurikulum 2013 - Aprilia Muktirina 


\title{
Gambar Ilustrasi Buku Sekolah Dasar \\ Ditinjau dari Teori Psikologi Persepsi
}

\author{
Asidigisianti Surya Patria \\ Universitas Negeri Surabaya \\ asidigisianti@yahoo.co.id
}

\begin{abstract}
Abstrak
Gambar ilustrasi dalam buku-buku pelajaran SD tampilanya kurang menarik dan kurang memperhatikan aspek psikologi anak. Padahal esensi gambar dalam buku pelajaran adalah mengkonkretkan penjelasan teks pada pelajaran tersebut. Mengingat usianya anak SD lebih mudah memahami gambar dari pada ribuan kata. Ketika mengamati sebuah gambar ilustrasi sebagai objek persepsi visual, pengamat (anak) memperhatikan secara menyeluruh kemudian mencari detail-detail dari gambar tersebut dengan menggunakan prinsip ilmu jiwa Gestalt.Gambar ilustrasi dalam buku Sekolah Dasar merupakan penangkapan persespsi eksternal dari anak. Sebagai penarik perhatian anak, gambar ilustrasi menganut prinsip ilmu jiwa Gestalt. Gaya gambar kartun dapat menjadi pilihan dalam mengilustrasikan teks dalam buku SD. Mengingat prinsip gambar kartun yang sederhana dengan menghilangkan detai-detail gambar.
\end{abstract}

Kata kunci: gambar ilustrasi, buku SD, psikologi persepsi

\section{Pendahuluan}

Pendidikan Nasional berdasarkan Pancasila dan Undang-Undang Dasar Negara Republik Indonesia Tahun 1945 berfungsi mengembangkan kemampuan dan membentuk watak serta peradaban bangsa yang bermartabat dalam rangka mencerdaskan kehidupan bangsa, bertujuan untuk mengembangkan potensi peserta didik agar menjadi manusia yang beriman dan bertakwa kepada Tuhan Yang Maha Esa, berakhlak mulia, sehat, berilmu, cakap, kreatif, mandiri, dan menjadi warga negara yang demokratis serta bertanggung jawab tanpa memperhatikan jenis kelamin (baik laki-laki maupuan perempuan). Untuk mengemban fungsi tersebut pemerintah menyelenggarakan suatu sistem pendidikan nasional sebagaimana tercantum dalam Undang-Undang Nomor 20 Tahun 2003 tentang Sistem Pendidikan Nasional.

Salah satu implementasi dari Undang-undang Pendidikan Nasional adalah kurikulum sekolah. Dalam penyusunan kurikulum selalu mempertimbangkan sumber belajar dan media pembelajaran yang dibutuhkan dan sudah tersedia sehingga memungkinkan siswa memperoleh pengalaman belajar secara nyata, bermakna, luas dan mendalam. Sumber belajar adalah bahan-bahan yang dapat dimanfaatkan dan diperlukan untuk membantu pengajar maupun siswa dalam proses pembelajaran. Sumber belajar dapat berupa buku teks, media cetak, media elektronik, nara sumber, lingkungan alam sekitar, dan sebagainya yang dapat meningkatkan kadar keaktifan dalam proses pembelajaran. Sumber belajar dipilih berdasarkan kompetensi, materi pembelajaran, kegiatan pembelajaran dan indikator pencapaian kompetensi dasar. Penggunaan sumber belajar yang tepat akan menunjang keefektifan proses pembelajaran (Munir, 2008:131).

Selain sebagai sumber belajar buku teks termasuk juga dalam media pembelajaran berbasis cetakan (Arsyad, 2005:87). Fungsi media pembelajaran menurut Halmanik (1986 dalam Arsyad, 2005:15) harus dapat membangkitkan keinginan dan minat baru, membangkitkan motivasi dan rangsangan kegiatan belajar, dan mempengaruhi psikologis siswa, serta membantu siswa meningkatkan pemahaman siswa.

Kerucut Dale merupakan penjabaran media pembelajaran dari tingkat yang paling kongkret berupa pengalaman langsung ke tingkat yang paling abstrak yaitu lambang kata. Semakin ke atas semakin abstrak media penyampaiannya. Tingkat keabstrakan akan semakin tinggi ketika dituangkan ke dalam lambang-lambang seperti bagan, grafik atau kata. Bila ditambahkan lambang visual tingkat akan lebih kongkret (Arsyad, 2005:11). Dalam kerucut tersebut gambar visual menduduki tingkat lebih rendah dibandingkan dengan kata-kata atau tulisan, artinya gambar visual lebih mudah dipahami dibandingkan dengan uraian kalimat. 
Azwar (1993, dalam Iriaji 2006) mengemukakan bahwa keberadaan gambar illustrasi dalam buku teks akan semakin bermakna dan strategis nilainya, manakala diletakkan dalam bingkai pendidikan di jenjang sekolah dasar kelas awal. Hal tersebut lebih dikarenakan masih terbatasnya kualitas perkembangan psikis individu dalam hal kemampuan berfikir abstrak. Pesan visual yang paling sederhana, praktis, mudah dibuat dan banyak diminati anak pada jenjang pendidikan dasar adalah gambar terlebih gambar berwarna (Sudjana, 2001:10). Hasil studi juga menunjukkan bahwa anak SD lebih menyenangi gambar berwarna daripada hitam putih, memilih foto daripada gambar, dan memilih gambar realism.

Gambar dalam buku pelajaran disebut juga dengan Ilustrasi. Jadi ilustrasi ialah seni gambar yang dimanfatkan untuk memberi penjelasan suatu makna atau tujuan secara visual. Bentuk ilustrasi dapat berupa: sketsa, lukis, grafis, desain dan kartun (Susanto, 2002: 53). Ilustrasi buku berperan penting dalam penyampaian materi agar siswa dapat lebih mengkongktretkan kata-kata abstrak dalam materi pembelajaran. Dalam buku-buku pelajaran di Sekolah Dasar juga menampilkan ilustrasi-ilustrasi sebagai penunjang pokok bahasan atau materi. Gambar-gambar ilustrasi tersebut merupakan visualisasi dari materi yang disajikan dalam buku tersebut. Gambar ilustrasi tersebut dapat dikaji dari segi kesenirupaan tanpa meninggalkan konten atau materi yang ingin disampaikan penulis kepada pembaca dalam hal ini siswa SD.

Selama ini gambar-gambar ilustrasi dalam buku-buku pelajaran SD sangat memprihatinkan, selain tampilanya kurang menarik juga berkesan asal tempel banyak juga yang diunduh dari internet tidak diedit atau digambar ulang, sehingga tampak kurang memperhatikan aspek psikologi anak. Padahal esensi gambar dalam buku pelajaran adalah mengkongkretkan penjelasan teks pada pelajaran tersebut. Mengingat usianya anak SD lebih mudah memahami gambar dari pada ribuan kata. Hal ini berbalik dengan kenyataan yang ada pada bukubuku pelajaran SD yang ada banyak kata gambar sedikit dan kurang jelas serta berkesan over entertaining dan terlalu detail bagi anak SD.

\section{Prinsip Gambar Ilustrasi}

Gambar ilustrasi dalam kajian Seni Rupa, yang utamanya sebagai penjelasan dari suatu cerita ataupun pengetahuan, misalnya pada terbitan buku, majalah, Koran dan sebagainya, yang memuat beberapa kejadian dan disinilah peranan gambar ilustrasi sebagai penjelasnya. Gambar ilustrasi bi- asanya ditampilkan berdampingan dengan sebuah cerita, baik cerita pendek maupun cerita lainnya. Maka gambar-gambar misalnya berupa kerangka manusia dan binatang, tumbuh-tumbuhan dalam buku biologi dan dapat disebut sebagai gambar ilustrasi. (Sulistyo, 2006: hal 104-105)

Gambar ilustrasi adalah gambar yang disajikan bersama teks, sebagai bagian dari atau pendam-ping untuk teks, baik untuk menambah daya tarik teks maupun untuk memperjelas maksud teks. Ilustrasi pada dasarnya turut menafsirkan teks, atau sekurang-kurangnya berupaya memperhidup teks melalui citra visual. Dalam hal ini ilustrasi dapat dibedakan dengan iluminasi meskipun pada umumnya dan dalam perkembangan sejarahnya ilustrasi dan iluminasi berjalan beriringan bahkan berpautan sedemikian eratnya. Namun untuk kepentingan analitis, keduanya bisa dibedakan satu dari yang lainnya. Jika iluminasi merupakan gambar yang cenderung hanya menjadi dekorasi bagi teks, ilustrasi merupakan gambar yang cenderung ikut menjadi interpretasi atas teks (Setiawan, dkk, 2006: 350). Sehingga dapat disimpulkan bahwa gambar ilustrasi merupakan gambaran singkat suatu alur cerita guna lebih menjelaskan cerita atau teks tersebut, bisa digunakan dalam majalah, surat kabar maupun buku bahkan buku pelajaran.

Azwar (1993 dalam Iriaji, 2006) menyebutkan bahwa gambar illustrasi dalam keterkaitannya dengan buku teks memberikan petunjuk bahwa gambar dapat menyediakan informasi verbal dan membuat informasi tersebut dapat diterima lebih konkrit, tentu bila digunakan secara efektif. Bila gambar-gambar disisipkan dalam buku pelajaran, maka gambar tersebut dapat membantu pembelajaran untuk mengorganisir informasi dan dapat memperjelas konsep-konsep yang rumit. Selain itu gambar dapat memberikan kemudahan dalam kemampuan pemahaman, jika gambar diintegrasikan dengan kata-kata. Alasannya adalah bahwa gambar membuat kata-kata yang tertera di teks menjadi lebih bermakna bagi pembelajar. Demi semakin mengefektifkan kualitas hasil si pembelajar pengggunaan gambar illustrasi dalam buku teks sebaiknya mempertimbangkan beberapa faktor, diantaranya adalah tujuan pembelajaran dalam tingkat kelas yang menggunakannya.

\section{Persepsi Visual}

Persepsi dalam bahasa Inggris perception berasal dari bahasa Latin perceptio; percipere secara etimologis, berarti menerima atau mengambil. Dalam Rakhmat (2005) menurut Desiderato (1976) Persepsi adalah pengalaman tentang objek, peris- 
tiwa atau hubungan-hubungan yang diperoleh dengan menyimpulkan informasi dan menafsirkan pesan. Persepsi memberikan makna pada stimuli inderawi (sensory stimuli).

Salah satu Faktor yang sangat mempengaruhi persepsi adalah perhatian. Kenneth E Anderson mendefinisikan perhatian adalah proses mental ketika stimuli dan rangkaian stimuli menjadi menonjol dalam kesadaran pada stimuli lainnya melemah. Jadi perhatian akan timbul bila mengkonsentrasikan diri pada salah satu indra dan mengesampingkan masukan indra lainnya. Ketika menyeleksi rangsangan dari luar melalui alat indra kita dipengaruhi beberapa faktor, yang dibagi dua kelompok besar, yaitu: faktor internal dan eksternal. Faktor internal adalah faktor-faktor yang berkaitan dengan diri sendiri (personal) sedangkan faktor eksternal adalah faktor mempengaruhi persepsi dari luar individu. Faktor Internal yang mempengaruhi seleksi persepsi adalah sebagai berikut: kebutuhan biologis, latar belakang, pengalaman, kepribadian, sikap dan kepercayaan umum, penerimaan diri. faktor eksternal yang mempengaruhi seleksi persepsi adalah sebagai berikut: intensitas, ukuran, kontras, gerakan ulangan, keakraban dan sesuatu yang baru (Rakhmat, 2005:52).

Persepsi menurut David Kerch dan Richard (Rakhmat, 2005:51-56) ditentukan oleh dua faktor, yaitu: faktor fungsional dan faktor struktural. Faktor fungsional berasal dari kebutuhan, pengalaman masa lalu dan hal lain yang disebut dengan faktor personal. Keduanya juga merumuskan dalil persepsi yang pertama bersifat selektif secara fungsional, artinya obyek mendapat tekanan dalam persepsi biasanya obyek yang memenuhi tujuan individu yang melakukan persepsi. Kerangka rujukan (frame of reference) yang disebut juga faktor fungsional misalnya adanya pengaruh kebutuhan, kesiapan mental, suasana emosinal dan latar belakang budaya terhadap persepsi.

Faktor yang kedua yang menentukan persepsi adalah faktor struktural yaitu faktor yang berasal dari stimuli fisik dan efek syaraf yang ditimbulkan pada sistem syaraf individu tersebut. Prinsip ini dikenal dengan teori Gestalt, yaitu: dalam mempersepsi sesuatu individu mempersepsi bukan melihat bagian perbagian tetapi melihat secara keseluruhan. Salah satu tokohnya adalah Kohler. Ia berpendapat apabila memahami suatu peristiwa tidak akan diteliti secara terpisah melainkan menghubungkan keseluruhan bagian menjadi satu kesatuan. Jadi bila memahami suatu individu perlu juga melihatnya dalam konteks, lingkungannya dan masyarakatnya. (Rakhmat, 2005: 58).
Cara berpikir visual berdasarkan pola persepsi adalah alamiah dalam rangka mencari esensi berpikir visual diawali dengan melihat pola visual yang ada secara menyeluruh tanpa melihat detail baru kemudian menganalisa secara rinci bentuk visual tersebut. Ketika menganalisa pola secara detail melibatkan atensi dan kebutuhan individu (Couto, 2010:35). Hal ini juga terjadi ketika mengamati sebuah gambar ilustrasi sebagai obyek persepsi visual, pengamat memperhatikan secara menyeluruh kemudian mencari detail-detail dari gambar tersebut. Pencarian persepsi visual dengan melihat detail menggunakan prinsip ilmu jiwa Gestalt.

Ilmu Jiwa Gestalt yang merupakan salah satu cabang psikologi yang berkembang di Jerman. Gestalt adalah bahasa Jerman yang tidak dapat ditemukan padanan katanya secara tepat dalam bahasa Inggris. Kata yang mendekati Gestalt adalah form (bentuk), configuration (susunan) atau pattern (pola). Gestalt menekankan bahwa keseluruhan mempengaruhi pernyataan setiap bagian yang maksudnya persepsi bertindak menarik daya sensosrik menjadi suatu pola keseluruhan atau Gestalt jadi bila kita mempersepsikan sesuatu, tidak akan bisa bagian perbagian secara terpisah-pisah melainkan secara keseluruhan utuh. (Attkinson dkk, 1983:209).

Fenomena persepsi yang dikemukakan oleh ahli psikologi Gestalt dinyatakan sebagai sebagai organisasi perpsepsi, dengan hukum kesederhaan (Law of Simplicity), yaitu penghayatan yang berkaitan dengan penafsiran stimulus termudah dan termungkin. Pegorganisasian fenomena persepsi dibedakan menjadi dua yaitu Gambar dan Latar Belakang (figure dan ground effect) dan pengelompokan persepsi (perseptual grouping) (Verbeek, 1978:51).

Hubungan antara gambar dan latar belakang (figure dan ground effect) diciptakan oleh Edgar Rubin (Sobur, 2003:484). Disini gambar merupakan pusat pengamatan sedangkan latar belakang merupakan suatu lingkungan yang seolah-olah tak terbentuk. Gambar merupakan hal primer dan berkontras dengan latar belakang serta menonjolkan diri. Latar belakang bersifat sekunder, kurang penting dan kurang terorginisir. Berdasarkan hubungan-hubungan umum tersebut dapat dipahami beberapa konsep mengenai gambar dan latarnya Gambar (figure) dilihat dari wujudnya memiliki bentuk yang jelas sedanngkan latar belakang tidak memiliki bentuk. Figure memiliki struktur yang jelas sedangkan latar belakang strukturnya buram atau tidak jelas. Pada figure juga terlihat batas-batas berupa garis yang membedakan dengan latar- 
nya sedangkan latar belakang tidak memiliki batas (unlimited). Apabila dilihat dari posisinya terlihat jelas bahwa figure berada di depan sedangkan latar tentunya dibelakang (Verbeek, 1978: 52).

Adanya kecenderungan pengamat untuk kegiatan mengorganisir kesan-kesan sensori visualnya membentuk suatu Gestalt yaitu: satu kesatuan utuh atas sebagian-sebagian yang membentuk hubungan hubungan dengan menggunakan hukum "law of simplicity". Hukum ini menggunakan penghayatan yang berkaitan dengan penafsiran stimulus termudah dan termungkin. Misalnya: apabila melihat mobil, kita tidak melihat bagian-bagian dari mobil, misalnya rodanya, tetapi melihat mobil secara utuh (Verbeek, 1978:53).

\section{Psikogi Perkembangan Anak}

Anak usia SD (7-11 tahun) dalam teori Piaget termasuk dalam Tahapan Operasional Konkret. Dalam tahapan ini anak mampu berpikir secara logis yang diaplikasikan secara konkret dan spesifik. Anak tidak mengkonservasi secara serentak tetapi tahap demi tahap dimulai dari jumlah, panjang kuantitas zat cair, massa, berat dan volume. Ciri lain dari berpikir secara operasional konkret menurut Teori Piaget adalah kemampuan mengklasifikasi dan memahami hubungan diantaranya. (Santrock, 2007:255-257).

Meskipun anak usia Sekolah Dasar belum berpikir seperti orang dewasa mereka masih berakar pada dunia ini sebagaimana adanya dan mengalami kesulitan ketika harus berpikir secara abstrak. Jadi jenis oprasional dalam pemecahan masalah adalah membumi, kongkret dan berpikir praktis serta berpijak pada realitas yang dapat dipahami dan disimpulkan tepat dihadapannya. Anak-anak pada tahap ini dapat membentuk konsep, melihat hubungan, dan memecahkan masalah tetapi hanya sejauh melibatkan obyek dan situasi yang sudah dikenal. (Slavin, 2008:53)

Pendapat ahli psikologi lain mengenai pencitraan gambar (pictoral imagery) pada anak, yaitu bagaimana anak menggambarkan suatu obyek (manusia maupun benda). Werner (Crain, 2007:142-143) berpendapat bahwa anak masih dalam taraf pengalaman primitif yaitu masih dalam taraf berpikir konkret dan belum mencapai tahap murni konseptual. Pada orang dewasa sudah berpikir sinkretik yaitu: berpikir pada tingkat murni konseptual dengan menggunakan kategori umum dan abstrak. Sedangkan anak-anak dominan memiliki pencitraan eidetic (sesuatu yang terlihat) atau disebut juga memori fotografik, yaitu: beripikir secara tunggal tetapi mendetail.
Werner (Crain, 2007:144-148) juga berpendapat bahwa anak-anak memiliki persepsi fisiognomik, yaitu cara berpersepsi bahwa dunia memiliki jiwa atau perasaan. Hal ini sangat berbeda dengan persepsi orang dewasa yang berpersepsi geometris teknis yang lebih realistik dan menyentuh fakta sesungguhnya, yang banyak dimiliki oleh ilmuwan dan teknisi. Dalam persespsi fisiognomik terdapat adanya emosi di dalam bebatuan, dahan kayu, cangkir dan obyek tak berjiwa lainnya. Bagi orang dewasa yang rasional hal ini tidak dapat dipercaya karena lebih memandang lingkunga secara impersonal dan apa adanya. Berbeda dengan anak-anak, mereka memahami lingkungan penuh kehidupan dan gerakan. Mereka memahami dunia secara alamiah dan berjiwa seperti apa yang mereka rasakan dalam dirinya.

\section{Gambar Ilustrasi Buku Sekolah Dasar dalam Persepsi Visual}

Buku pelajaran sebagai media pembelajaran harus dapat membangkitkan keinginan dan minat baru, membangkitkan motivasi dan rangsangan kegiatan belajar, dan mempengaruhi psikologis siswa, serta membantu siswa menigkatkan pemahaman siswa. Buku pelajaran tidaklah menarik apabila hanya berupa tulisan tanpa dibumbui dengan gambar ilustrasi.

Gambar ilustrasi pada buku pelajaran di Sekolah Dasar (SD) pada dasarnya merupakan gambaran singkat suatu alur cerita yang berfungsi untuk menjelaskan cerita atau materi pembelajaran. Gambar ilustrasi disini sebagai pendukung materi pelajaran dalam buku SD sehingga gambar yang ditampilkan harus memberikan penjelasan terhadap materi tersebut bukan malah membingungnkan anak atau bahkan mengganggu perhatian anak terhadap pelajaran tersebut.

Gambar-gambar ilustrasi dalam buku pelajaran yang merupakan salah satu penerapan seni rupa, mempunyai fungsi utama sebagai penjelas dari materi (pembelajaran) yang ada di dalam buku pelajaran tersebut. Gambar yang ditampilkan tidak akan lepas dari materi yang disajikan. Materi yang disajikan secara visual tentunya akan lebih menarik bagi anak daripada hanya dalam bentuk tulisan atau teks semata. Bagi anak usia Sekolah Dasar gambar ilustrasi menjadi hal yang lebih diminati dibandingkan dengan tulisan yang panjang lebar.

Berdasarkan konsep perpsepsi vuisal anakanak yang membumi, kongkret dan berpikir praktis serta berpijak pada realitas yang dapat dipahami dan disimpulkan tepat dihadapannya. Gambar ilustrasi buku pelajaran SD sebaiknya menggambar- 
kan atau mengilustrasikan obyek yang dekat dengan anak dan berada di lingkungan anak. Misalnya keluarga dan alam sekitar. Hal ini akan menjadi permasalahan apabila gambar yang ditampilkan cenderung mengarah pada lingkungan kota yang berkarakter modern dan canggih penuh dengan gadget. Anak SD yang berada di desa akan tidak paham dan tidak mampu membayangkan realitas tersebut. Disinilah perang ilutrastor dalam memvisualisasikan kondisi lingkungan dan sekitar anak. Jangan sampai condong ke arah lingkungan tertentu, seharusnya imbang dan berusaha netral.

Pemahaman lingkungan menurut anak berdasarkan persepsi fisiognomiknya, (Werner dalam Crain, 2007) anak cenderung berpersepsi bahwa tumbuhan, hewan atau benda mati lainnya sama dengan dirinya yang memiliki jiwa. Anak berpikir obyek tersebut memiliki perasaan dan emosi. Hal ini dapat menjadi pertimbangan illustrator bahwa memvisualisasikan obyek benda mati maupun hewan dan tumbuhan seharusnya tidak memasukkan unsur kekerasan atau penyiksanaan pada obyek tersebut.

Dalam psikologi persepsi faktor internal yang menyangkut diri sendiri (personal) pada anak SD tidak mudah dipengaruhi dalam jangka waktu singkat karena menyangkut kebutuhan biologis, latar belakang, pengalaman, kepribadian, sikap dan kepercayaan umum, serta penerimaan diri. Sedangkan faktor eksternal yang mempengaruhi persepsi anak SD melalui intensitas, ukuran, kontras dan sesuatu yang baru dalam gambar ilustrasi buku pelajarannya. Faktor-faktor eskternal ini juga berkaitan dengan faktor yang struktural merupakan faktor yang berasal dari stimuli fisik dan efek syaraf yang ditimbulkan pada sistem syaraf anak SD tersebut.

Gambar ilustrasi dalam buku SD ditangkap sebagai faktor persepsi dari luar (faktor ekstenal), dengan demikin gambar ilustrasi secara langsung mempengaruhi persepsi struktural anak SD sehingga merangsang sistem syaraf melalui stimuli fisik dengan melihat gambar-gambar ilustrasi tersebut. Dengan mempertimbangkan persepsi psikologi perkembangan anak usia SD yang menyangkut memori fotografik (beripikir secara tunggal tetapi mendetail) yang dimiliki anak ilustrasi pada buku SD tidak melibatkan banyak gambar yang bevariasi melainkan tunggal tetapi digambarkan dengan terperinci semirip dengan konsep berpikir anak yang membumi.

Gambar ilutrasi sebagai obyek yang mempengaruhi faktor eskternal psikologi persepsi sebagai penarik perhatian. Dengan perhatian berarti anak mengkonsentrasikan diri pada indra penglihatan (mata) dan mengesampingkan masukan indra lainnya untuk melihat gambar ilustrasi tersebut sehingga gambar ilusatrasi seharusnya mempertimbangkan intensitas, ukuran, kontras dan sesuatu yang baru sehingga anak menjadi tertarik untuk melihat gambar ilustrasi tersebut. Intensitas, ukuran dan kontras berkaitan erat dengan faktor struktural psikologi perpsepsi yang berlandaskan pada teori Gestalt.

Berdasarkan prinsip teori Gestalt figure dan ground, gambar ilustrasi buku SD lebih menekankan obyek tunggal sebagai figure sedangkan ground tidak perlu mendetail. Perhatian utama anak terpusat pada obyek figure bukan ground yang berlebihan. Gambar figur dengan merupakan gambar primer sebagai pusat perhatian yang berwujud dan berada di depan serta kontras dengan latar belakang dan menonjolkan diri. Penerapan teori gestalt Law of Simplicity juga menjadi bagian penting dalam psikologi persepsi anak SD. Tetap berdasarkan psikologi anak yang berpikir kronkrit dan praktis. Gambar ilustrasi yang yang ditampilkan juga bersifat sederhana dalam hal komposisi bentuk dan warnanya.

Foto dengan penuh warna alami, rendering tiga dimensi, dan nuansa warna yang terlihat aslinya memiliki kerincian dan tinggi. Sedangkan gambar yang memiliki kerincian rendah adakah garis, siluet dan ikon. Gambar tersebut menggunakan sedikit elemen visual yang berkualitas rendah. Pengurangan unsur realisme dari suatu obyek realis adalah dengan dengan mengurangi kerinciannya tersebut.

Dengan meminimaliskan gambar akan membaut fase sisntem informasi anak lebih efisien. Saat anak menangkap gambar grafis sederhana kemudian memahami informasi yang terkandung di dalamnya, disini memori yang bekerja kemudian terjadi penampilan ulang di dalam internal informasi lalu menterjemahkannya. Dengan gambar berkerincian rendah membantu gambar tersebut siap menuju informasi jangka panjang. Beberapa ahli kognitif berpendapat bahawa manusia mengkode gambar seperti sketsa dan karton karena gambar tersebut mengalami pengurangan realisme sesuai dengan apa yang diinginkan otak manusia. Dengan adanya penyederhaan gambar akan membutuhkan sedikit usaha untuk mengenali obyek tersebut dan kemudian menyiapkan ke dalam memori jangka panjang (Malamed, 2011: 103-104).

Penyerderhanan gambar dapat berupa penyerderhanaan garis-garis gambar sehingga gambar yang ditampilkan mengarah pada gaya gambar kar- 
tun. Kartun pada dasarnya merupakan bentuk penegasan melalui penyederhanaan dari usaha pencitraan yang dirancang menyerupai subyek terutama manusia dengan menghilangkan detail (Mc Cloud, 1994:30). Artinya seorang kartunis menggambar suatu obyek tanpa harus menekankan detail visual obyek sebagaimana ilustrator gambar realis tetapi lebih mementingkan detail kartun itu sendiri di antaranya ekspresi, pergerakan (movement /arcs), focus skala dan teknik pemberian warna serta bayangan.

Penyederhanaan gambar secara universal dan fitur seperti gambar anak-anaklah yang membuat kartun disukai anak-anak diamana kartun menyedot identitas dan kesadaran ke dalam ruangan kosong dimana bisa menjelajahi dunia lain/khayal. Dengan demikian pesan yang akan disampaikan melalui kartun tersebut akan lebih mudah dipahami daripada bebertuk realis dengan banyak detail (McCloud, 1994:36). Hal lain yang menyebabkan kartun disukai anak-anak adalah anak-anak merupakan kartunis sejati di dunia nyata karena gambaran mereka merupakan penyerderhanaan dari dunia nyata yang dipahaminya secara sederhana. Anak-anak menggambar kartun tanpa bersusah payah (Hamm, 1983). Salah satu contoh penyederhanaan dari foto (realisme) sampai dengan bentuk karton adalah gambar wajah sebagai barikut:
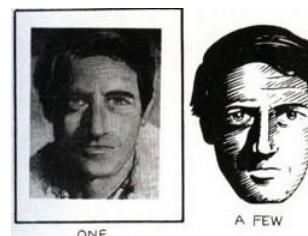

Gambar 1. Proses Penyederhanaan Wajah Manusia menjadi Kartun (Sumber: Scott McCloud.1994.)

Proses penyederhanaan dari gambar kenyataan atau realis (reality) menjadi gambar yang bermakna dapat dilihat pada segitiga kosakata gambar (Pictural Vocabulary) di bawah ini. Di sebelah kiri bawah merupakan kenyataan yang berdarsarkan visual atau pandangan mata semata. Semakin ke kanan menjadi bentuk ikonik bermakna (kartun) yang melibatkan tidak hanya visual tetapi juga proses berpikir. Sedangkan semakin ke atas mengerucut menjadi gambar bidang datar yang tidak bermakna.

Gambar kartun sebagai gambar ilustrasi untuk buku pelajaran SD berada pada posisi yang dilingkari. Visualisasi gambar tidak reaslistik seperti foto ataupun tidak abtrak tetapi berada di tengah diantara keduanya. Gambar realistik disederhanakan tetapi rinci sesuai dengan psikologi perkembangan anak yang masih berpikir tunggal tetapi rinci.

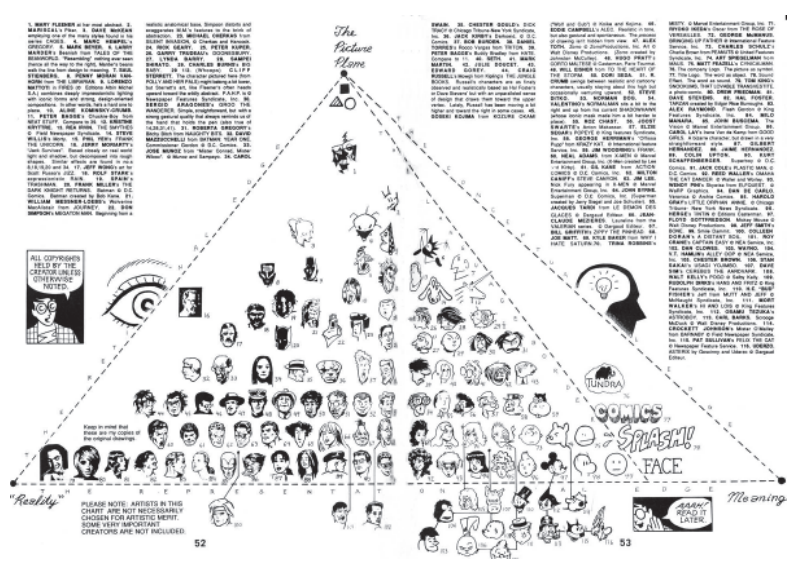

Gambar 2. Pictural Vocabulary. Antara Kenyataan (Reality), Maksud (Meaning) dan Bangun Datar (Picture Plane)

(Sumber: Scott McCloud.1994. Understanding Comic)

Penyederhaan bentuk realis selain karton adalah line art. Seni garis (line art) merupakan Salah satu jenis gambar yang melalui porses penyederhaan. Gambar ini memfokuskan pada outline dari obyek. Hanya dengan beberapa goresan dan kedalaman value atau tone rendah gambar garis tersebut menggambarkan bentuk obyek. Line art tidak merlukan kerincian tinggi tetapi harus mampu menangkap kontur dan fitur-fitur obyek dengan menyaring informasi yang tidak relevan. Ilustrator hendaknya menganalisis dan memilih sedikit elemen yang mampu menghadirkan ide, emosi atau obyek tersebut. Melalui proses visual, otak mencerna dengan cepat garis-garis gambar karena ketika anak memindai gambar aktivitas visual tersebut mengacu pada ujung garis. Begitu pula dengan siluet, dimensi siluet membuat anak lebih mudah mengenali obyek tersebut (Malamed, 2011: 122).

\section{Sistem pencernaan amfibi}

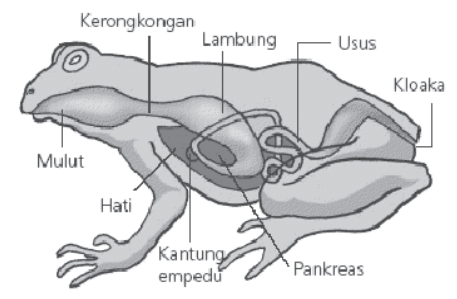

Gambar 3. Penggunaan Line Drawring dalam IPA. (Sumber:http:// riabiologiuad.blogspot.com/2012_07_01_archive.html

Dengan menggunakan jenis gambar karton ataupun line art dalam gambar ilutrasi pada buku Sekolah Dasar diharapkan akan membantu anak memudahkan memamahi teks yang ada dalam buku. Anak akan lebih mudah dalam memproses obyek atau gambar ilustrasi tersebut masuk kedalam memori jangka panjangnya. 


\section{Kesimpulan}

Gambar ilustrasi dalam buku Sekolah Dasar merupakan penangkapan persespsi eksternal dari anak. Sebagai penarik perhatian anak, gambar ilustrasi menganut prinsip ilmu jiwa Gestalt. Gambar ilustrasi dalam buku hendaknya lebih menekankan figure daripada ground dengan memberikan kontras tinggi pada keduanya, baik dari segi bentuk maupun warna. Penerapan prinsip Law of Simplicity dengan menampilkan gambar-gambar yang menyederhanakan garis. Gambar realistik disederhanakan tetapi rinci sesuai dengan psikologi perkembangan anak yang masih berpikir tunggal tetapi rinci.Gaya gambar kartun dapat menjadi pilihan dalam mengilustrasi-kan teks dalam buku SD. Mengingat prinsip gambar kartun yang sederhana dengan menghilangkan detai-detail gambar.

\section{Pustaka}

Arsyad, Azhar, (2005). Media Pembelajaran. Jakarta: Raja Grafindo Persada: p. 11, 131

Atkinson, Rita L; Atkinson, Richard C dan Hilgard, Ernesy, (1983). Pengantar Psikologi, Jakarta: Penerbit Erlangga: p. 209.

Couto, Nasbahry, (2010). Psikologi Persepsi dalam Kawasan Desain Komunikasi Visual, Padang: UNP Press: p. 35.

Crain, William, (2007). Teori Perkembangan: Konsep dan Aplikasi. Yogyakarta: Pustaka Pelajar: p. 142-143.

Hamm, Jack, (1983). Drawing Head and Figure. London: Perigee Book

Iriaji, (2006). Pengembangan Gambar Ilustrasi Berperspektif Jender pada Buku Teks Sekolah Dasar Kelas Awal. Dalam Jurnal PENELITIAN KEPENDIDIKAN Tahun 16, Nomor 2, Des 2006. Malang: UNM Press.

McCloud, Scott, (1993). Understanding Comic. New York: First Harper Perennial

Malamed, Connie, (2011). Visual Language for Designer. Beverly, Mass USA: Rockport : $p$ 103-104, 122.

Munir, (2008). Kurikulum Berbasis Teknologi Informasi dan Komunikasi. Bandung: Penerbit Alfabeta: p.131

Rakmat, Jalaluddin, (2005). Psikologi Komunikasi, Bandung: Remaja Rosdakarya: p 51-56, 58.

Santrock, John W., (2007). Perkembangan Anak. Jakarta: Penerbit Erlangga: p. 255-257.

Setiawan, H. W., Damajanti, Irma \& Sunarto, Prijanto, (2006). Telaah Atas Ilustrasi Buku Roesdi djeung Misnem sebagai Bacaan MuridMurid Sekolah Rakyat di Jawa Barat sebelum Perang Dunia II. Jurnal Visua Art. Vol. 1 D,
No. 3, 2007, 346-363. Bandung: ITB: p. 350.

Slavin, Robert E, (2008). Psikologi Pendidikan Teori dan Praktik Edisi Kedelepan Jilid 1. Jakarta: PT Indeks: p. 53.

Sobur, Alex, (2003). Psikologi Umum, Bandung: Pustaka Setia: p. 484.

Sudjana, Nana dan Rivai, Ahmad, (2010). Media Pengajaran. Bandung: Sinar Baru Algensindo: p. 10.

Sulistyo, Edi Tri, (2006). Kaji Dini Pendidikan Seni. Surakarta: Universitas Negeri Surakarta (UNS) Press: p. 104-105.

Susanto, Mikke, (2011). Diksi Rupa: Kumpulan Istilah dan Gerakan Seni Rupa. Yogyakarta: DictiArt Lab \& Djagad Art House Tim MGMP.1996. Pendidikan Seni. Surabaya: Trijaya Pustakaraya: p. 53.

Verbeek, H.Th, M., (1978). Pengamatan. Yogyakarta: Penerbitan Yayasan Kanisius: p. 51-52. 